\title{
Public Culture
}

Han Hyung-mo had a reputation among his colleagues as "Korea's coolest guy." This exalted status derived in large part from his enthusiastic embrace of modernity and his cosmopolitan worldliness. Like Helen Kim in the field of education and Lee Tai-young in law, Han was a native modernizer of South Korea's film industry and its cinema (figure 6$)^{1}$

Han's ostentatious modernity formed the core of his professional identity. In interviews years later, his colleagues recalled the manner in which he lived and worked as expressions of his open-mindedness and individualist ethos, qualities that set him apart from the era's more typically conservative directors and that made him appear uniquely "ahead of his time." At a moment when many directors were just getting by, Han flaunted his sophisticated lifestyle, living in a Westernstyle house filled with foreign décor and driving himself around Seoul in a private car. $^{2}$ Han was as open to new ideas about filmmaking as he was to new ideas about life. He traveled to Tokyo to buy equipment, to Hong Kong and Manila to attend international film festivals, and even to California to get inspiration on film studio design. He borrowed freely from foreign films and filmmaking practices, and introduced technical and aesthetic changes that reverberated across the industry. Han used his skills to capture Korea's dynamic new culture and society as it was taking shape. Critics singled out his films for their attention to "modern society," "modern lifestyle," "modern environment," "modern theme," "modern sense," "modern emotion," and "modern morals." ${ }^{3}$ Han devoted his energies, above all, to the representation of the modern woman, and his career reached its apogee in a cycle of women's pictures he directed between 1954 and 1961. Because Han's films appealed to both popular and critical tastes, he was one of the few directors able to 


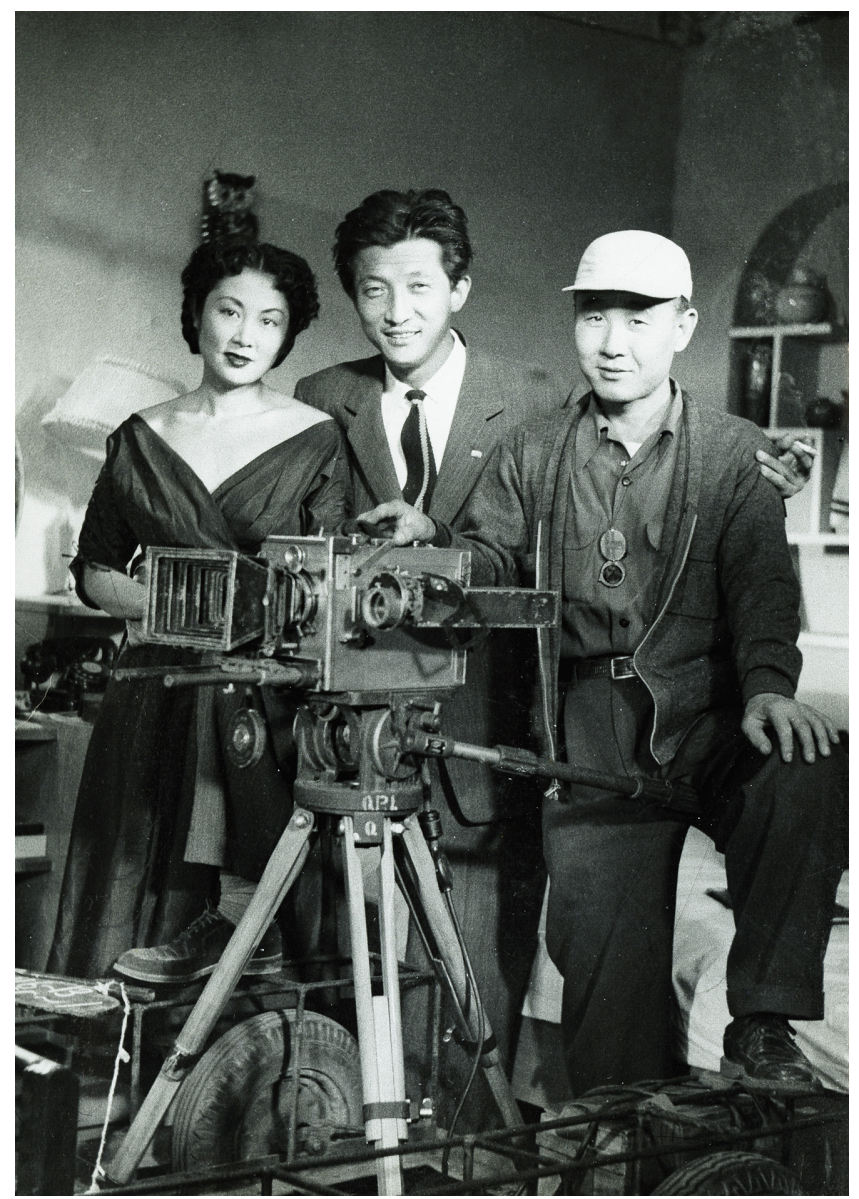

FIGURE 6. Han Hyung-mo (right) on the set of The Hand of Destiny.

maintain a steady flow of production. He was the postwar era's commercial filmmaker par excellence, and in this he was extraordinary.

In other ways, however, Han was a common postwar figure: the creative, entrepreneurial, market-savvy cultural producer who understood Koreans' desire for something new. Seen in this light, Han can be understood as kin to Heo Gi-suk, a resourceful woman credited with the invention of budae jjigae, or army base stew. While jjigae, or stew, has long been a staple of Korean cuisine, local lore holds that Heo created this particular version in Uijeongbu during the years of desperate poverty after the Korean War. Like Han, Heo was open to new ideas. She worked as a cook in one of the numerous American army bases (budae) and smuggled out processed meats such as Spam, hot dogs, sausage, and ham, for which she was 
frequently arrested. Budae jjigae was born when she put this American meat into a traditional kimchi-laden broth and began selling it on the streets of the camptown that surrounded the bases. Over the years, other industrially processed ingredients were added, most notably ramyŏn, a version of the instant ramen noodles that were invented in Japan in 1958 and made in Korea with imported American wheat. ${ }^{4}$ Mongrel as it was, budae jjigae appealed to Korean tastes and soon became part of the national cuisine.

I want to take budae jjigae as a metaphor for Han's films and postwar cultural production more generally. Heo's creativity was widely shared among South Koreans: for all its social and economic dislocations, South Korea in the 1950 also experienced a robust cultural boom. As in many postcolonial and postwar societies, there was an unleashing of pent-up creative energy as artists and intellectuals took advantage of greater freedoms and a gradually improving economic situation. The film industry occupied the apex of this cultural rebirth. It experienced tremendous growth beginning in 1955-56, and by the end of the decade was both the most technologically advanced culture industry and the producer of the most popular forms of cultural expression. At the pinnacle of that industry was Han Hyung-mo.

The notion of "budae jjigae cinema" invites us to think about this cultural boom within the framework of the Cold War. Not only did the film industry's products convey anticommunist, capitalist, and democratic ideologies; they were also produced with the aid of materials made available by the waging of the Cold War. Washington's efforts to integrate South Korea into the Free World produced pools of resources that inventive South Koreans drew upon during these lean years. Some of these resources were material in nature; others were textual. Many of them ended up in the hands of South Koreans, who used them to create new forms of culture-movies as well as food. From this perspective, the scope of the cultural Cold War extends beyond state-directed cultural projects and into the efflorescence of indigenous cultural production. The idea of budae jjigae cinema also invites us to recognize the cosmopolitan intermingling of Korean and foreign elements - the cultural equivalents of kimchi, Spam, and ramyŏn, as it werewithin this efflorescence. Korea's relationships with the United States, Japan, and other Free World countries shaped postwar cultural production in overt and subtle ways. "Budae jjigae cinema" invites us to see the suppressed presence of Japan in postwar cultural production, alongside the more manifest influences of America.

"Budae jjigae cinema" also calls attention to two modes in which Koreans became cultural producers: as poachers and as cultural entrepreneurs. By poaching, I mean the act of taking without asking within profoundly unequal relations of power, and the incorporation of that material into new cultural production. Heo Gi-suk, for example, poached the meat that she used to create budae jjigae. Drawing on the ideas of Michel de Certeau, Miriam Hansen, and Henry Jenkins, I am using the term both literally, to suggest the theft of material goods, and metaphorically, 
to refer to the textual appropriation of expressive resources. ${ }^{5}$ Poaching implies an insurgent claim to power by the weak against the strong; it is a gesture of challenge as much as one of affiliation, and as an assertion of independence it has an implicit political dimension. Poaching was a vital mode of cultural production in the postwar period, as later chapters will explore. South Koreans also acted as Cold War cultural entrepreneurs, which is to say that they seized the opportunities for creative and professional advancement that the Cold War was opening up. ${ }^{6} \mathrm{Heo}$, for instance, took advantage of the opportunity to work in a US military kitchen and in the market that the military bases created. (Syngman Rhee was undoubtedly Korea's most outstanding Cold War entrepreneur, brilliantly working his relationship with the Americans to keep the aid spigot open.) To think of Korean cultural producers such as Han Hyung-mo as poachers and entrepreneurs is to highlight their diverse forms of agency and creativity amidst difficult conditions and drastically unequal relations with the United States.

"Budae jjigae cinema" captures the particular experience of cultural modernity in South Korea in the 1950s. What's interesting here is not the simple achievement of modernity, but rather how that modernity was defined, created, and debated locally. Arjun Appadurai and Carol Breckenridge coined the term public culture to characterize the arena in which this happens and to call attention to the diversity of players, which include mass media industries, the state, and individual cultural producers. Their concept of public culture makes room for a critical engagement with consumption as a powerful imaginative act, one that can expand the horizons of possibility with sometimes emancipatory effects. It also makes room for foreign actors, who often exert an outsize influence in postcolonial societies. Public cultures outside the West thus frequently become incubators of what Appadurai and Breckenridge call a "new cosmopolitanism," as national, transnational, mass, and folk cultures interact with and cannibalize each other. ${ }^{7}$

South Korea's postwar public culture was just such an incubator. Home to a growing number of producers and consumers, it was deeply penetrated by transnational forces. The US military, the Asia Foundation, Hollywood, the Japanese film industry, European intellectual trends, and global popular music trends all contributed to budae jjigae cinema. As a result, public culture served as a site in which postwar modernity was produced as well as consumed. ${ }^{8}$ As discussed in chapter 1, Korea in the 1950 s lacked the solid economic foundation of industrial modernity. Postwar modernity was thus in many ways a cultural phenomenon, a matter of ideas and attitudes, practices and representations.

This chapter parallels chapters 1 and 2 in its attention to the historical development of Cold War cosmopolitanism, focusing here on its emergence within public culture. It charts TAF's interventions in this arena, paying particular attention to its efforts to nurture a cosmopolitan consciousness among South Koreans and to cultivate their personal, institutional, and commercial ties within Free Asia. The chapter explores the country's cultural rebirth in the wake of the Korean War, and shows 
how TAF fostered the growth of cultural institutions and encouraged the production of high-quality magazines and movies. Two developments take center stage: the emergence of the woman-in-public as a visual icon of modernity, and the rise of the film industry to the apex of public culture. These developments come together in the career of Han Hyung-mo, who was both a modernizer of Korean cinema and one of the most important producers of the figure of the modern Korean woman.

\section{CULTURAL REBIRTH: THE ROLE OF THE ASIA FOUNDATION}

South Korea's cultural rebirth took place across many dimensions of public culture. Institutions such as museums and libraries were rebuilt. Select traditional arts were resurrected, including poetry, archery, and some performing arts. Popular music-live, broadcast, and recorded-became increasingly accessible. Commercial venues of leisure and entertainment-dance halls, pool halls, restaurants, teahouses, coffee shops-flourished and became the foundation for a new enjoi lifestyle. Fashion appeared, as younger women embraced Western styles of dress and older women modernized their traditional hanbok with new fabrics. The rapid expansion of the education system - there were nearly eighty thousand college students by 1961 - contributed to this cultural growth, expanding the pool of cultural consumers and fostering the emergence of a liberal intelligentsia. As Charles Kim has shown, this flourishing public culture became the site of robust debates, as artists and intellectuals vigorously interrogated the terms of Korea's much-desired modernization. ${ }^{9}$

The Asia Foundation intervened very intentionally in Korea's public culture, actively seeking to shape the discussions about-and production of-modernity taking place there. The foundation understood with a sophistication unmatched by any other US agency that indigenous cultural production was a central arena for waging the Cold War. It recognized that local mass media were vitally important tools for disseminating democratic and anticommunist ideas, and it established numerous programs to ensure a steady supply of newspapers, magazines, and books sympathetic to US aims. More significantly, TAF had a highly developed understanding of the social and political roles of music, literature, and the arts. In an internal 1962 report summarizing the foundation's arts philosophy and providing guidance for future programming, research fellow George Lerski urged all TAF representatives to recognize the "cultural scene" as a barometer that could give them "an indication of the direction in which society [was] heading" and to develop the skill to read these cultural signals. Support for the arts could also promote healthy nationalism, healing social divisions between urban and rural populations and bridging the gap between old and new ways of thinking. ${ }^{10}$

More ideologically, TAF regarded creativity as a distinctly Free World value intrinsically bound up with individualism. In contrast to communists, who purportedly 
valued art as a tool of indoctrination, Lerski claimed that "the unrestrictive artistic expression with its creative right of doubt and even error is one of the main attractions possessed by the pluralistic societies of the Free World in the struggle for human minds." The foundation also valued culture as an economic realm, which meant that promoting media and the arts could do double duty as economic development. It was also politically wise, since artists, writers, and intellectuals were potentially volatile social actors whose "frustration" at a lack of opportunity might lead them to "radical solutions." For TAF president Robert Blum, public culture was a crucial realm in which the United States must exercise its power-it was "one of the elements we have to influence in order to make our policies effective." ${ }^{11}$

Korea was at the forefront of TAF's commitment to culture, receiving more support for the arts than did any other office. Even before the establishment of the Seoul office in mid-1954, the Tokyo office in 1952-53 developed a program for Korea that promised to "encourage the artist, build up his ranks, unite the people under a developing indigenous culture, and link cultural progress to freedom under democracy." ${ }^{12}$ This cultural vision was greatly expanded in October 1955, when the Seoul office produced its "Plan for Korea," a master blueprint that articulated the foundation's objectives and laid out a roadmap for programming. The report's unnamed author, almost certainly Mary Walker, was greatly encouraged by signs of creative "ferment" and reported that the "Korean talent for music, art, and literature is slowly emerging with . . . amazing vitality." The Plan proposed to encourage this vitality, setting as its objective nothing less than the "renaissance of Korean culture." Such a rebirth was deemed critically important after the "cultural disaster" of Japanese colonialism, which fractured Korea's existing culture and tried to remake its people as "secondary" Japanese, who were "not quite as good as the real thing but who had no other cultural alternatives." The new nation's spiritual and political existence was at stake: "The Republic must re-create a Korean culture in order to maintain its identity," an identity defined in opposition to that of North Korea. ${ }^{13}$ As Tokyo representative Delmer Brown had noted a few months earlier, the partition of the peninsula in 1945 had created a "laboratory situation" in which free and communist ways of life were being tried out side by side, and the world was watching. ${ }^{14}$ In keeping with this ambition to nurture a new and distinctly South Korean culture and identity, TAF representatives in Seoul funded numerous projects that had a national scope. They donated equipment to enable the National Museum to catalogue its collection, gave funds for the creation of a hangul dictionary that would help rationalize the national language, and encouraged the revival of the mask dance, a folk cultural form that had been banned by the Japanese. As George Lerski proclaimed, "cultural heritage is an ally." 15

The 1955 "Plan for Korea" balanced this sensitivity to nationalism and cultural heritage with a forceful articulation of Cold War cosmopolitan ideals. It made clear that worldliness must be an essential component of Korea's postcolonial culture. The desired "renaissance" could not consist exclusively of the revival of Korean 
traditions: the few remnants of "archaic" culture that had survived colonialism were "hardly" able to "serve a modern society." Instead, a distinctly modern culture should be cultivated through sustained engagement with "Western models." The national and the cosmopolitan were thus partners in a dual project of nation building and bloc building: a distinctly South Korean national culture would be enmeshed within a network of Free World ties even as it was being born. To this end, the Plan identified as one of its core objectives the "Korean adaptation of Free World cultural experiences to Korean use." TAF sought to midwife into existence a culture rooted in indigenous traditions yet open to Western ideas and engaged with cultural developments across the democratic world. Adaptation was a core feature of what was, in effect, a plan for cultural modernization: Western patterns would "not serve Korea without tailoring to size," and the Plan pledged to identify those Koreans who would be "capable of managing the adaptation." The Plan's cosmopolitan vision also entailed making Korean culture more visible abroad. TAF regarded Korea not simply as a recipient of foreign ideas, but also as an active contributor to world culture. The export and exhibition of Korean culture across the Free World was thus another of the Seoul office's core objectives. The Plan called for programming that would develop "in Asia and other democratic countries ... an understanding of Korean culture and respect for the developing expression of this culture." ${ }^{16}$ This objective had clear political underpinnings. TAF was adamant that the Republic of Korea become globally visible as a newly independent nation whose postwar reconstruction had been financed largely by the United States. Korea's modernity - a product of its alignment with the West-must be displayed alongside its cultural heritage for all the world to see.

As the Seoul representatives made grants designed to bring this new nationalcosmopolitan Korean culture into existence, they explicitly encouraged the activities of cultural entrepreneurs. To think of Korean artists, intellectuals, and civic leaders as entrepreneurs is to recognize the extent to which the waging of the cultural Cold War entailed opening up new creative and professional opportunities for select individuals. As part of its efforts to win "hearts and minds," the Asia Foundation willingly made resources available and invited Koreans to take advantage of them for their individual creative and professional advancement, as well as for the social impact that such advancement would deliver. Cold War entrepreneurs were Koreans who took advantage of these opportunities and resources. Sometimes they did so out of a shared commitment to the foundation's values and goals, such as anticommunism or artistic freedom; for others, more opportunistic motives may have been at work. Unlike poachers, who took without asking and often in secrecy, entrepreneurs availed themselves in broad daylight of what the Asia Foundation freely offered.

The writer Oh Young-jin was a classic Cold War entrepreneur who translated his personal experiences with communism into professionally advantageous relationships with Americans. A North Korean refugee, Oh began his South Korean 
career writing and publishing anticommunist books and magazines. He developed relationships with USIS personnel, helped TAF's Tokyo office forge contacts with Korean cultural organizations during the Korean War, and in 1953-54 toured the United States on a State Department Leaders Grant. The Seoul representatives supported his magazine Literature and the Arts, awarded its Freedom Literature Award to a book he published, and tried to find an American publisher for his own memoir about life under communism. They fostered his intellectual engagement with the Free World by providing subscriptions to Western magazines, and in 1959 financed his participation in Henry Kissinger's Harvard International Seminar, which brought together leaders from across the Free World and immersed them in American life. Oh was a cosmopolitan intellectual who possessed the interpersonal and linguistic skills to work easily with Americans, and he developed close personal relationships with Asia Foundation staff. Representative Jack E. James said of Oh, "I do not think we could find anyone who represents so well the intellectual, creative Koreans or who can speak of their problems so well." Oh was just the type of worldly intellectual TAF was looking for: he is "one of the few Korean intellectuals," wrote James, "who is attempting to understand where Korea stands in relation to the cultural community of the world and what are the best contributions she can make to that community." ${ }^{{ }_{17}}$ Building on this assistance from TAF and other US agencies in his early years, Oh went on to become a prominent postwar screenwriter, playwright, and critic.

\section{WOMEN AS ICONS OF MODERNITY: YŎWŎN}

Print culture received steady support from TAF's Seoul office. Immediately after the Korean War, program advisor Cho Tong-jae reported that the publishing industry was on the verge of collapse. Magazine publishers in particular were in "desperate need of help," reported TAF representative Lawrence Thompson: "Unless we give prompt first-aid, the patient may die waiting for the doctor." The issue was a shortage of newsprint. Korea's paper factories had been heavily damaged during the war, and those that remained lacked the resources and skilled labor to make full use of their capacity. Imported paper was very expensive, black-market paper even more so, and corrupt publishers were diverting aid dollars to illegal money traders. In response, the representatives began making direct grants of paper intended to keep a magazine in print for six months, during which time the publisher could hopefully accumulate sufficient capital to restore economic self-sufficiency. Once a grant was made, TAF claimed to exercise "absolutely no editorial control." By the mid-1950s the newsprint program was one of the foundation's most important initiatives, receiving over ten thousand dollars each year. Through these "transfusions" of paper the Seoul office "saved the life of practically every one of the betterquality periodicals in Korea at one time or another." ${ }^{18}$ Partially as a result of this aid, Korea developed what Gregg Brazinsky has characterized as an "astonishingly 
rich and diverse print culture."19 Serial publication flourished, and by 1960 there were 536 weekly and monthly periodicals authorized to publish. These periodicals, in turn, supported the publication of over one thousand books annually. ${ }^{20}$

TAF's support for print culture intersected with its interest in Korean women. The Seoul office gave substantial support to Yŏwŏn (Woman's garden), Korea’s premier women's magazine. Publisher Kim Ik-dal launched Yowon in October 1955 and Mary Walker made the first paper grant in October 1956, noting that the Seoul office had observed its first year of publication with "keen interest." "It is our feeling," she wrote, "that this magazine can do much to raise the status of women in your country." This initial grant was followed by an additional one in 1957, when it received more paper than any other magazine, and another in 1959. TAF regarded Yǒwŏn as a high-priority project, praising its twenty-six-year-old female editor Kim Kwi-hyun as "brilliant" and arranging an internship for her at Better Homes and Gardens after she completed graduate training in journalism at the State University of Iowa. ${ }^{21}$ (She became further enmeshed in Cold War transnational networks when one of her Ewha professors recommended her to the Committee of Correspondence for a 1957 international workshop.) $)^{22}$ Yŏwŏn, in turn, helped further TAF's mission by occasionally publishing articles written by its employees.

Yŏwŏn became a key site for the visual production of modernity, which emerged within its pages as a combined social, political, and cultural project. Yŏwŏn was a substantial publication, in terms of its physical size (issues ran between two hundred fifty and four hundred pages), its audience (educated women, housewives, intellectuals, college students), and its monthly readership (forty thousand by 1958 and sixty thousand by 1963). ${ }^{23}$ It offered diverse perspectives on a wide variety of social and political topics, published fiction and poetry, and covered the film industry carefully through articles, reviews, and advertisements. It was an image-rich publication, full of photographs, drawings, paintings, diagrams, advertisements, cartoons, maps, sheet music, and clothing patterns. It presented itself as a manual to modern life, offering visual instruction in modernizing women's everyday activities, from the use of labor-saving appliances like the electric iron to the new social practice of dating. Western fashions appeared prominently, as did photographs and floor plans for Western-style houses. Overall, it communicated an optimistic attitude: modernity wasn't something women should fear, but something they could master and transform into a source of new pleasures and efficiencies.

Yǒwŏn undertook the cosmopolitanizing cultural work of mapping the capitalist-democratic world and imaginatively integrating South Korea into it. In the process it constructed a visually rich Cold War global imaginary. Between 1957 and 1959 it published scores of maps and photographs that brought the Free World into existence as an imagined community. It depicted the cultures of European countries (England, France, West Germany, Spain, Denmark, the Netherlands), explained the contested parts of the globe (Hungary, Suez, Algeria, Tibet, Cuba), 
and introduced fellow members of Free Asia (Taiwan, Philippines, South Vietnam, Pakistan). It even illuminated the global military network in which South Korea was enmeshed, publishing several maps depicting US and Soviet military bases across the globe. Less overtly, the magazine carried Japan's ghostly presence into public culture: its layout was very similar to the leading Japanese women's magazine, Shufu no Tomo (The housewife's friend), indicating both the legacy of colonial ties and the extent to which Korean cultural producers looked to Japan as a culturally proximate model of modernity that they could emulate. ${ }^{24}$

Gender emerged in Yŏwŏn's pages, as elsewhere in public culture, as the key symbolic language through which the costs and benefits of modernity were weighed. Women's bodies, their activities, and the spaces they inhabited became the grounds on which public intellectuals mapped the profound social changes taking place around them. ${ }^{25}$ Due to the pace and scope of changes taking place in actual women's lives, representations of women became barometers of South Korea's transformation, particularly of the impact of Western ideas and practices. Korea was hardly unique in this respect. Given women's association with childbearing and the private realm of the family, they have long served, in Asia and the West alike, as instruments for measuring the impact of modernity on existing social norms. ${ }^{26}$

Yŏwŏn played a crucial role in constructing the modern Korean woman, and the woman-in-public, as a specifically visual icon. The opening pages of each issue were devoted to her representation. The cover featured a color painting or photograph of a young woman, almost always dressed in Western attire and with bobbed hair (figure 7). This was followed by ten to thirty-five pages of black-andwhite photographs, most of which focused on contemporary women in a variety of contexts and situations. A second, similar photo spread appeared later in the magazine. In the pages of Yŏwŏn, women appear comfortable in public space: they walk freely in the streets and spend leisure time in coffee shops and at the beach. Occasionally they are represented in sexually suggestive ways that echo American pinups; other times they display their bodies as skilled athletes. Women who border on social respectability, including café waitresses and prostitutes, are depicted thoughtfully. The Asia Foundation supported this visual production directly and intentionally: its first grant was for a supply of special offset paper that enabled the magazine to publish more photographs.

The magazine ran a number of photo series that highlighted different aspects of the modern woman and the routes through which she was entering public life. "Blooming Girls" extended a colonial-era New Woman trope and featured photographs of students at elite high schools and women's colleges, sometimes accompanied by captions identifying their professional aspirations. ${ }^{27}$ The magazine devoted substantial visual attention to the working woman, making her the subject of several photo series. "Happy Today: Working Women" launched in the inaugural issue of 1955, followed three years later by "Young People's Lives," about working 


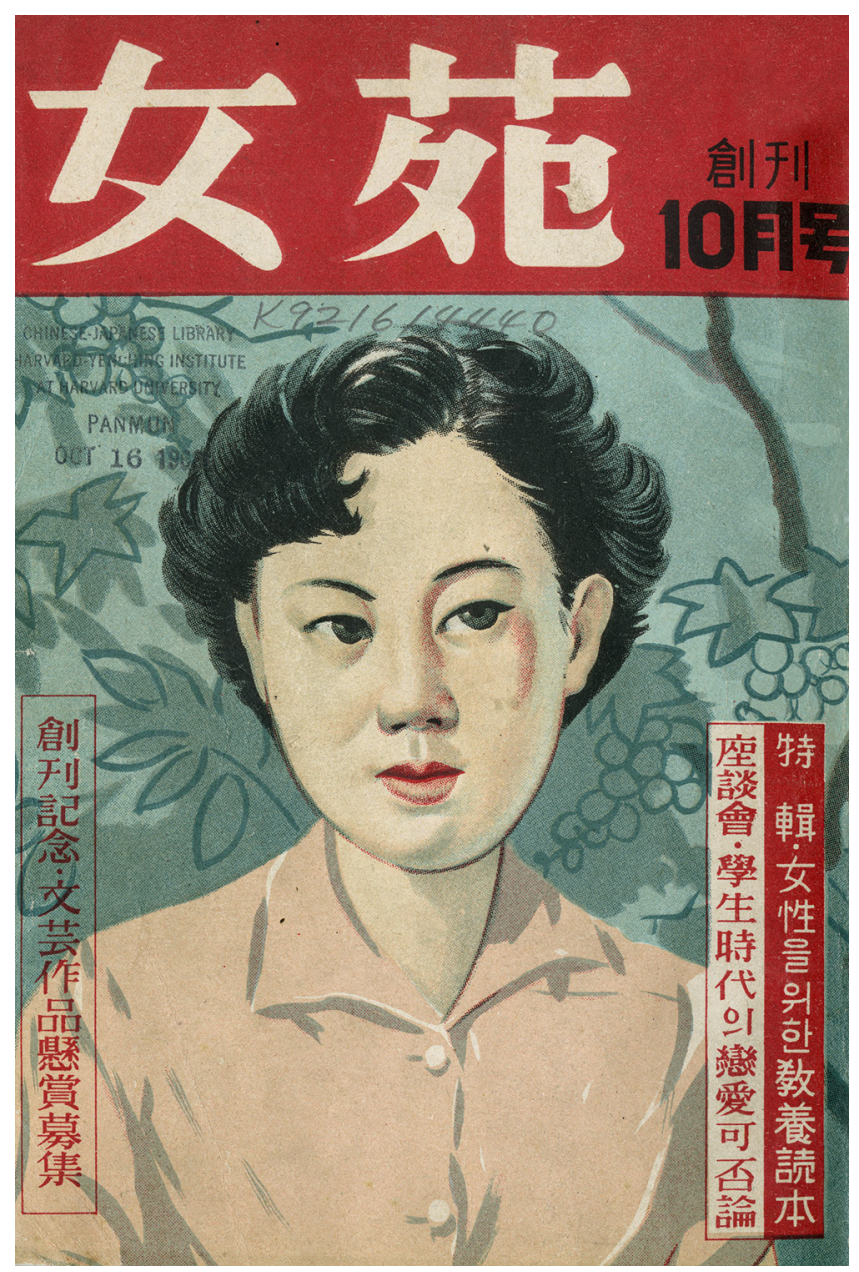

FIGURE 7. The first issue of Yŏwŏn magazine, October 1955.

women such as a textile factory worker and a nurse. ${ }^{28}$ The most innovative series was "Cutting-Edge Jobs," which ran through most of 1958. It showed women working in occupations that fell far outside their traditional domain, including the first female chief editor of a magazine, a script girl at a film company, and a shorthand transcriber at the National Assembly. ${ }^{29}$ One entry in this series showed a woman behind the wheel of a large American car, that evergreen symbol of modernity and autonomy (figure 8). The accompanying caption, which identified her as a taxi driver, noted that she had received good-driving awards from her current employer, the UN's Office of the Economic Coordinator (the main distributor of US aid), thereby reinforcing the association of women's progress with the West. 


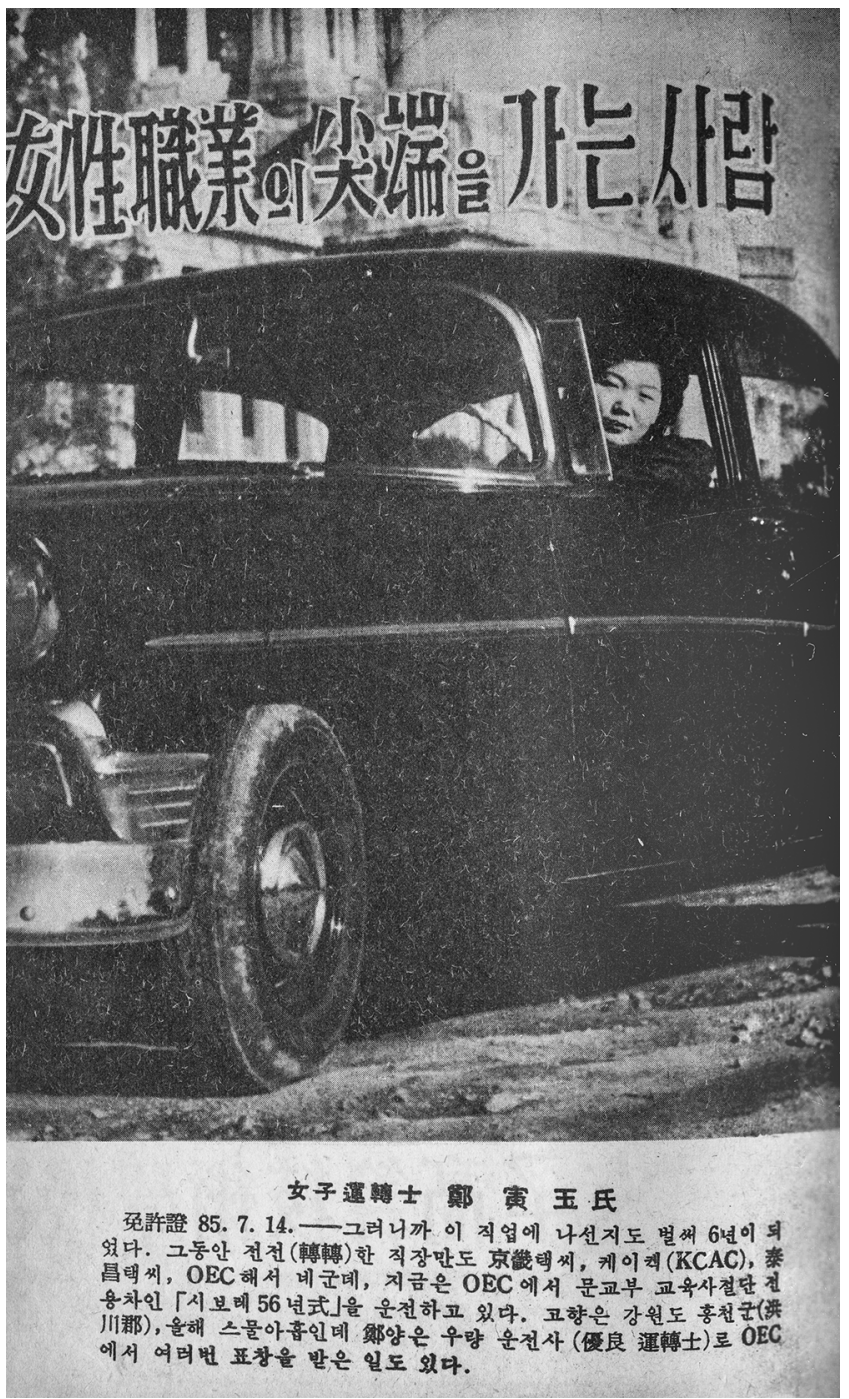

FIGURE 8. Female taxi driver in the series "Cutting-Edge Jobs," Yŏwŏn, March 1958.

These photo series supported the editors' pronouncement, published in the third issue, that "there has never been a time when the position of working women in society has been as conspicuous and important as the present." ${ }^{30}$

"Twelve Modern Korean Women" ran throughout 1956 and gave its subjects pride of place at the end of the opening pictorial section. It featured older women dressed in hanbok who visually evoked traditional gender roles, but were in fact 
formidable professionals and artists who held positions of authority in the public sphere. Among them were Im Yeong-sin, former minister of commerce and industry and member of the National Assembly; Im Suk-jae, president of Sookmyoung Women's University; and Mo Yun-suk, poet. These are portraits of individuals, rather than images of representative types. Each photograph occupies a full page, and the women's upright poses and forthright gazes convey a sense of selfpossession. Their modernity was marked through their accomplishments and, often, their association with the United States: many of these women had ties to the United States, and more than half of them had received State Department leadership grants. Several of them sit behind large, imposing desks that serve as the white-collar equivalent of the taxi driver's car: visual emblems of authority in the public sphere. Lee Tai-young and Helen Kim, the era's most prominent women-inpublic, appeared in the July and August installments (figures 4 and 5 in the preceding chapter). Kim and Lee also appeared regularly in Yŏwŏn's pages as authors and subjects of numerous articles, many of which linked women's liberation to democracy. Lee even wrote a regular legal advice column under the assertive headline "Female Lawyer Tae-young Lee in Charge." ${ }^{11}$

While Yŏwŏn did not speak with a single voice and often published articles espousing a postcolonial traditionalist position, ${ }^{32}$ it did serve as a prominent venue for the expression of Cold War cosmopolitan feminism. As Lee and Kim's presence suggests, it amplified the voices of female modernizers and Cold War cultural entrepreneurs. The magazine served as a forum for women who had traveled to the United States via State Department leadership grants and agreed to publicize their experiences upon their return home. Between 1955 and 1961, it published at least thirty-seven pieces about America by twenty-three highly accomplished Korean women, including a serialized novel by Kim Mal-bong set in Washington, DC. Overwhelmingly positive, these writings extended the work of the cultural Cold War by disseminating, via local voices, carefully curated visions of the United States. They also attested to the creative and professional benefits that accrued to those women who were able to access American resources, both financial and institutional. In Yǒwŏn's pages, professional women were often framed in relation to the United States and depicted as inhabitants of a public sphere that extended far beyond Korea.

The magazine's linkage of the modern woman with the world beyond Korea's borders found perhaps its fullest expression in "Miss Earring's World Adventure" of 1961. In this eleven-part series of articles and photographs, an unseen and unnamed female traveler brings the reader on a tour through the Free World. ${ }^{33}$ She begins in the Free Asia (Japan, Hong Kong, the Philippines, Laos, India), moves on to the US-allied Middle East (Israel, Turkey), and ends up in Western Europe (France, West Germany, England). This series is comparable to contemporary around-the-(free)-world travel articles that appeared in American magazines such as the Saturday Review, and it served a similar pedagogical function. ${ }^{34}$ 
"Miss Earring" brings the Free World into existence as an entity that is intellectually accessible to South Koreans, mapping it as an interconnected series of distinct locales whose differences are charming rather than threatening. Her travels around the globe bring the abstract ideal of freedom to life: the transnationally mobile female subject works as a dual metaphor for the expanding sphere of action open to the modern South Korean woman and the liberties that the noncommunist world offers. ${ }^{35}$

\section{HAN HYUNG-MO AND THE REBIRTH}

OF THE FILM INDUSTRY

The film industry, like magazine publishing, also flourished in the 1950s. Han Hyung-mo was the leading commercial filmmaker of the 1950s, working across and excelling at virtually all aspects of film production. Between 1949 and 1967 he directed nineteen films, edited sixteen, and served as cinematographer on fifteen; he worked as a producer and an art director, and was known as a superb lighting designer. His films attracted large audiences, participated in international film festivals, won domestic and international awards, were singled out for praise by President Rhee, and earned the admiration of his peers. ${ }^{36}$ They were among the first Korean films to be commercially exported. ${ }^{37}$

Han's career developed in parallel with Korean political history from the $1940 \mathrm{~s}$ through the early 196os, as he took advantage of the opportunities that each new political situation made available. Han was one of the few filmmakers who spanned the 1945 divide. Han's early life and career took shape within the colonial system. He was born in 1917 into an affluent Christian family in Uiju, North Pyeongan province, where his father was a public official. An artistic youth, Han attended the Singyeong Arts School in Japanese-occupied Manchuria and worked as a sign painter at a department store. Han moved to Seoul and began his film career in 1941, as the colonial government was consolidating the film industry and orienting it more directly towards wartime propaganda. His first job was as the art director on Choi In-gyu's Street Angels (1941). Choi, one of the colonial era's leading directors, recognized Han's promise and took him on as a protégé. ${ }^{38}$ The Korean film industry during these years was largely adjunct to that of Japan, and personnel moved easily between them. ${ }^{39}$ Choi helped Han get professional training in cinematography at Japan's Toho studio from 1941 to 1943, where he apprenticed under Miyajima Yoshio and assisted on the wartime propaganda film A Story of Leadership (1941). After passing the cinematography exam, Han returned to Korea to work as Choi's cinematographer on two pro-Japanese films, Children of the Sun (1944) and Promise of Love (1945). ${ }^{40}$

Although the political turmoil and poverty of the liberation years inhibited the development of the industry as a whole, the emerging Cold War created opportunities that Han was able to seize. During the US occupation period, Han shot 
Choi's anti-Japanese liberation film Hurrah! for Freedom (1946), which was made with the support of USIS. ${ }^{41}$ Han made his directorial debut soon after the formation of the ROK with Breaking the Wall (1949), a feature film that dramatized the bloody Yeosu-Suncheon rebellion of October 1948. This was a violent leftist revolt against Rhee's newly formed government that began in the army's own barracks when soldiers refused to participate in the repression of an insurgency on nearby Jeju Island; it quickly spread to the civilian population and culminated in the declaration of a "Korean people's republic" in South Jeolla province. Korean military forces brutally suppressed the insurgency with US assistance, leaving the streets lined with corpses and an unknown number-estimates range from hundreds to thousands-dead. The revolt prompted a political crackdown: in its wake, Rhee pushed through passage of the loosely worded National Security Law, which enabled the suppression of virtually all dissent, purged suspected communists from the military and government, and led to the jailing of tens of thousands of civilians. ${ }^{42}$ Han's Breaking the Wall presented the rebellion via a family drama in which an ROK officer confronts, and is killed by, his communist brother-inlaw. Han made the film with the support of the Korean Ministry of Defense and presented the Army's actions in a favorable light. ${ }^{43}$ In doing so, he established a relationship with the Ministry of Defense that allowed him access to its filmmaking equipment and other resources for many years. This early film suggests Han's eagerness to engage with the crises of contemporary life, as well as his sympathy with Rhee's government and its politics of anticommunism.

The outbreak of the Korean War created new opportunities. After the box office success of Breaking the Wall, the Navy asked Han to make a film that would present that branch of the military in a similarly positive way. Han agreed and began developing A Man's Way, about the maritime pursuit of a smuggling gang bringing in goods from Macao. Han began filming in the southern city of Mokpo, with a script by Cold War cultural entrepreneur Oh Young-jin and one of the country's three naval ships as a set. The North Korean attack in June 1950 brought production to a halt. Han and his crew rushed their equipment and film stock to the frontlines at Daejeon, where they began shooting footage of the war. This ad hoc group went on to become the Ministry of Defense Film Unit, thereby deepening Han's relationship with the military. Han took the footage to Tokyo for editing, recorded a narration written by Oh Young-jin, and screened the completed documentary An Assault on Justice, Part 1 (1951) for international journalists at the UN foreign correspondents' club. The film created a sensation in both countries and with its sequel, An Assault on Justice, Part 2 (1952), which was completed with the assistance of USIS, conveyed both the immediacy of war and the government's position on North Korean villainy. It was a highly effective piece of wartime propaganda. It also propelled Han into a new job as a war correspondent for the US-based International News Service, which had better resources than the Ministry of Defense. ${ }^{44}$ 
The war decimated South Korea's fragile commercial film industry. In its sweep south, the North Korean army confiscated almost all of the existing film equipment and killed, kidnapped, or lured north many of the most talented filmmakers, including Han's mentor Choi In-gyu. After the armistice in 1953, Han resumed work as a cinematographer, shooting documentary "enlightenment" films for the ROK Office for Public Information, including A Woman Soldier (1954), about the Korean Women's Army Corps, and The Hill of the Immortal Bird (1955), a war film that emphasized friendship between Korean and American soldiers. ${ }^{45}$

The film industry's fortunes began to improve in $1955-56$, as the cultural Cold War in Asia was gaining steam. The Asia Foundation captured this turning point in a pair of reports, which to this day remain the most comprehensive surveys of the Korean film industry at this crucial moment. Both reports were written by John W. Miller, the foundation's Tokyo-based motion picture officer. Miller wrote the first report after a two-week tour of Korea in January 1955, during which he consulted with key figures involved in film, government, and foreign aid. Miller described a "disorganized industry" that was in such a state of "chaos" that it barely qualified as an industry at all. There were no major producers, no stable production companies, no organizations that owned their own equipment, and no sound or shooting stages. Camera and lighting equipment was extremely limited; film stock was rare and either outdated or expensively acquired on the black market; processing chemicals were old and often unstable. The available technical and material resources did "not meet minimum needs for the production of high quality pictures." Miller described the mode of production as a "handicraft operation," with a few "shoestring operators" engaged in "spasmodic activity" and limited to producing only a single film at a time. Competent screenwriters were rare, technicians' skills were low, and exposed film was processed by hand. The result was a small output of generally poor-quality films, of which only two or three had been able to recoup their producers' investment. The exhibition sector was equally hobbled, with only fifty-nine theaters in the entire country and these mostly filled with Hollywood and European films. ${ }^{46}$

Two years later, the situation had changed dramatically. In his second, lengthier report written in December 1956, Miller described a very different situation. "Film production is booming in Korea," he wrote, and "the film industry is now entering a crucial period of its growth and development." While the industry was still disorganized and many technical aspects of production still "primitive," it was displaying "an amazing new vitality" and entering into a "colorful period of development." Production capital was flowing "abundantly" into producers' hands, and the industry was in the midst of a "production boom," with an increase from twelve feature films in 1955 to about forty in 1956. These were "gold rush' days for both talent and technicians." Producers, directors, and production staff had begun following "internationally accepted production practices" while finding creative solutions to problems created by ongoing shortages (such as using bread 
dough to create bas-relief set decoration). Budgets were rising, and with them production values. The days of "chasing the sun" and building sets in "bombed out buildings" - as Han had done-were numbered. The exhibition sector was likewise strengthening and now contained ninety-four theaters devoted exclusively to motion picture exhibition (although most of them were "crowded, uncomfortable, and often unsanitary"), and more than one thousand mobile or semipermanent $16 \mathrm{~mm}$ projectors were in use. Enthusiasm for domestically made films was rising: Miller reported seeing "people in rags and near rags push their hard earned Hwan through the ticket sellers' window. College students who scarcely have enough to pay tuitions or buy their lunch, women apple sellers, and people working on construction road gangs, all attend the cinema." Even members of the intelligentsia, who had formerly scorned domestic films, were now being attracted into the theaters to see them. Among audiences a growing "star consciousness" was beginning to emerge, fed in part by two film fan magazines. While the industry still suffered from many material shortages and deficiencies in skill, Miller believed the corner had been turned. ${ }^{47}$ While researching his report, Miller published an article in Yŏwŏn that singled out Han's Madame Freedom (1956) for its attention to contemporary life and praised filmmakers' visual presentation of modern women, noting that they are "almost identical to the women you would meet on the street." 48

Miller's prediction proved correct, and over the next few years the film industry took off. From 18 films in 1954, filmmakers produced over 111 films in 1959, and the total audience for domestic films surpassed that for imported films. ${ }^{49}$ Rhee proudly proclaimed that films made by "our own hands are good enough to match foreign movies," and T. S. Kim boasted in The Korean Republic newspaper that "only the most popular foreign films can compete with the domestic ones in the number of cinema-goers." ${ }^{\circ}$ Korean films entered international film festivals, where they began winning awards, and were commercially exported to select freeworld markets in Asia and the West..$^{51}$ All sectors of the industry grew: by the end of the decade, South Korea had an estimated 242 theater screens, 118 actors, 74 production companies, 51 directors, 8 private processing labs, 4 commercial film studios, and 1 university film department. Han's career expanded alongside the film industry as a whole. He returned to directing with The Hand of Destiny (1954) and two years later released Hyperbolae of Youth (1956) and Madame Freedom, both of which attracted huge audiences. Han led the industry's production boom, releasing multiple films almost every year through 1961. Over the course of the 1950 a truly national film industry took shape, and by the late 1960 s South Korea was producing more than two hundred movies per year..$^{52}$

What enabled the film industry to explode in such a short period of time? The 1955-56 years saw a convergence of factors, which can be summarized as the encounter of creative and ambitious Korean filmmakers with newly available resources.

Like other cultural producers, filmmakers entered the postwar period with a backlog of pent-up creative energy and a burning desire to tell Korean stories. 
John Miller, like other Asia Foundation employees in Seoul, was struck by the creative juices he saw flowing among Koreans. He praised the "industriousness, ingenuity, and creative ability of Korean film makers," admired the "charming sets" they built on "improvised stages", and applauded the "great promise" and "frequent flashes of brilliance" he saw in their films. ${ }^{53}$ While filmmakers enjoyed relative creative freedom, they operated within political constraints. The National Security Law crimped the expression of political ideas, censorship laws limited representations of sexuality, and nationalist regulations forbade most representations of Japan. Some filmmakers ran afoul of these constraints, such as Lee Kang-cheon, whose Piagol (1955) became the first film banned under the National Security Law. According to Miller, however, the "majority of Korean producers" were "reasonably happy with the application of the present system," and "most differences of opinion"-although certainly not all-were "settled without resort to scissors." 54 Filmmakers enjoyed greater opportunities to craft stories and characters than they had had for many years.

This creativity and ambition came into contact with a variety of resources, arising from within and without the country. The influx of Hollywood films generated financial resources for some sectors of the industry. American and other foreign films had begun pouring into Korea in 1945, which Washington encouraged for both economic and ideological reasons. Always eager to penetrate foreign markets, Washington during the Cold War particularly valued the ability of films to convey the values of democracy, freedom, individualism, and capitalism. Hollywood films proved popular-according to Lee Sang-geun, head of publicity at Danseongsa Film Company, Koreans "love foreign films as if it's life-and-death"and soon dominated the market. 55 This influx initially impeded the production of Korean films as theater owners, who were a major source of production capital, shunned locally made films in favor of more lucrative foreign pictures. The cash generated by foreign films stimulated other sectors of the industry, however. Film import, distribution, and exhibition were all highly profitable endeavors in the 1950s, offering a better return on investment than most other business opportunities, and some of the revenue they generated was used to acquire projectors and screens, rebuild war-damaged theaters, and open new ones. (Oh Young imported Hollywood films to fund his anticommunist publishing enterprise.) Perhaps most importantly, foreign films expanded the market for all films by luring audiences away from traditional live theater. ${ }^{56}$

State support helped increase the flow of resources to Korean film producers. Rhee was eager to have a national film industry, and in an effort to bolster the industry's reputation he urged Koreans to recognize movie production as a worthwhile social activity that employed people who deserved the respect of their fellow citizens. He was also sensitive to producers' calls for protection from foreign competition and responded with targeted measures. In 1954 his government eliminated the 40 percent admissions tax on domestic films, allowing theater owners to 
return a larger share of box office returns to film producers. (The tax was restored in 1960, but at a lower rate)..$^{57}$ The administration also began granting producers of what it deemed the year's most "excellent" films a special license to import and distribute one foreign film, the profits from which could be used to fund a local production. Together, these regulations put substantial capital into the hands of producers, who used it to finance higher-quality films. The producers of Han Hyung-mo's films benefited from both these initiatives: The Hand of Destiny was released soon after the 1954 admissions tax repeal, and at least four of his films earned the special import license..$^{58}$

This increased access to capital intersected with filmmakers' creativity to produce Korea's first two blockbusters: Lee Gyu-hwan's Chunhyang Story (1955) and Han Hyung-mo's Madame Freedom, both of which handily outperformed their Hollywood competitors. Madame Freedom attracted about one hundred fifty thousand admissions, at a time when the average foreign film attracted thirty thousand viewers and when fifty thousand constituted a big hit. ${ }^{59}$ The film delivered a thirty-eight-fold return on its producers' investment and earned them a special import license; it was, in the words of one of Han's colleagues, a "big cash cow." Together with Han's Hyperbolae of Youth, which also sold more than one hundred thousand tickets in 1956, these hits demonstrated that domestic films could attract large audiences and generate substantial profits. ${ }^{60}$ Additional capital quickly became available to producers as, in John Miller's words, everyone from "wealthy fish merchants, importers, land owners, money lenders and gray marketers" began investing in the now-glamorous movie business. ${ }^{61}$ These blockbusters established a new production cycle: more investment capital meant higher budgets, which led to better-quality films, which attracted bigger audiences and generated greater profits, which were used to produce new films or invested elsewhere in the industry.

Some of the most successful producers and exhibitors used their profits to build Korea's first commercial production studios. The Samsung Film Company, producers of Madame Freedom, opened the Samsung studio in 1957, which was built to Han's specifications after he traveled to the United States to study the design of a studio at a California art school. ${ }^{62}$ Samsung's Western-style complex consisted of one large studio big enough to house the set of a small village, a second studio equipped with a soundstage, a temporary "set operating station," a dormitory, and a cafeteria. While spacious, it lacked its own equipment, so filmmakers had to bring in rented cameras and lights. A reporter for the Han'guk ilbo found Han's studio design to be a satisfactory version of the American ideal: "Although it is not as luxurious as the interior of the studio of Cecil B. DeMille in Sunset Boulevard," he observed, it has "an atmosphere suitable to a studio where film, a somewhat exotic art, is created." ${ }^{3}$ Hong Chan, one of Korea's richest men and owner of Seoul's premier Sudo Theater, which hosted Madame Freedom's forty-five-day run, opened the Anyang Studio on the distant outskirts of Seoul later the same year. Drawing 
on his close ties to Rhee, Chan spent an estimated $\$ 250,000$ on construction and imported over $\$ 200,000$ worth of the most up-to-date American film equipment, making Anyang the largest film studio in Asia at the time. Unfortunately, Korean technicians did not have the skills to use the equipment effectively, which caused several of the early films to fail at the box office, and by 1959 the studio was bankrupt. ${ }^{64}$ Han Hyung-mo, more so than Hong Chan, served as one of the Asia Foundation's "tailors," successfully adapting a modern American institution to fit the more modest Korean size.

The waging of the Cold War also contributed to the industry's growth, enabling Korean filmmakers to gain access to an array of material and immaterial resources. These included advanced technical training. Washington considered motion pictures to be the most effective medium of public communication in Korea, and since 1945 the USIS and its occupation-era predecessor, the US Army 502nd Unit, had produced a steady flow of newsreels, documentaries, educational films, and propaganda. The Americans hired Koreans to work as directors, cinematographers, sound recording engineers, lab technicians, and editors. ${ }^{65}$ These hiring decisions were both practical (it was cheaper to employ Koreans than to bring over Americans) and political (Washington wanted Koreans to be able to produce their own high-quality films). These employees worked with up-to-date equipment, learned American production techniques, absorbed the conventions of classical Hollywood storytelling, and made personal connections that facilitated access to equipment and other resources for years to come. Many of them went on to work in commercial cinema, where their superior skills made them the backbone of the expanding industry. (Kim Ki-young, director of The Housemaid [1960], one of the highest achievements of Golden Age cinema, began his directing career with the USIS-produced film Boxes of Death [1955] and other works of Cold War propaganda.) ${ }^{66}$ The film unit of the United Nations Korean Reconstruction Agency (UNKRA), although a much smaller operation, provided Korean filmmakers with similar opportunities for training and experience, as well as valuable personal connections. ${ }^{67}$ Korea's Ministry of Defense, whose Film Unit Han Hyung-mo had helped establish, likewise provided valuable experience to young filmmakers and became an important training institution for those who later entered the commercial industry. ${ }^{68}$

The waging of the Cold War also led to an influx of modern filmmaking equipment, which filmmakers accessed via US, UN, and ROK agencies. John Miller estimated that between 1955 and 1959, South Korean government agencies received about \$2 million dollars from the US and the UN to build studios and purchase modern film technology. The ROK Office of Public Information (OPI), Rhee's domestic counterpart to the USIS, received about \$1 million from UNKRA and the International Cooperation Administration (ICA) to construct a fully stocked, up-to-date film production studio and processing laboratory. The film units of other government agencies-most notably the Defense Ministry, but also the Ministries of Reconstruction and Education-also received major grants. ${ }^{69}$ While 
these facilities were intended for the production of information and propaganda films, commercial filmmakers had access to this equipment. Lee Hyung-pyo, head of the OPI film division, remarked in 1956 that its studio was in operation twenty-four hours a day and openly used by " 20 or so independent film companies." John Miller noted the same year that "the film staffs of all government agencies" engaged in "semi-officially sanctioned but informally run equipment rental and film processing activities" for commercial producers, the proceeds of which often lined their own pockets. Virtually all commercial filmmakers in 1956, including Han Hyung-mo, used OPI or Ministry of Defense recording studios to post-record their dialogue, music, and sound effects..$^{70}$ The USIS and UNKRA film units also occasionally made their own equipment available to commercial filmmakers. ${ }^{71}$ While the opening of commercial studios lessened filmmakers' reliance on government equipment, it did not completely eliminate it. Some theater owners, in turn, acquired surplus projection equipment from the US Military Far East Motion Picture Service, which upgraded its theaters in 1956 and discarded its World War II-era $35 \mathrm{~mm}$ projectors, or purchased projectors on the black market. ${ }^{72}$

\section{THE KOREAN MOTION PICTURE CULTURE ASSOCIATION (KMPCA)}

Of all the US and UN agencies pouring resources into Korea, only the Asia Foundation set out intentionally to nurture the commercial film industry and encourage the production of high-quality entertainment films. It did so largely through the person of John Miller. Miller began his career in California's commercial radio in the 1940 os before serving as an information officer in the Pacific theater during World War II and in Korea during the US occupation period. In the early 1950 s he moved into film production, working at Palmer Pictures, a small San Francisco company that made films for the Asia Foundation. TAF hired Miller in 1952 to serve as production supervisor on radio in Tokyo; when Radio Free Asia shut down, he became the radio and motion picture coordinator and TAF's primary film consultant. Throughout the 1950 os Miller surveyed commercial film industries and advised on film projects across Asia, and he became a passionate and eloquent advocate for commercial Asian cinema. ${ }^{73}$ Miller's work was directed from TAF's San Francisco headquarters by James L. Stewart, director of operations, and Charles M. Tanner, liaison to Hollywood, both of whom had close ties to Korea: Stewart had been director of USIS in Seoul before the Korean War, ${ }^{74}$ and Tanner had worked as a USIS film editor there. ${ }^{75}$ Miller also worked closely with TAF's local representatives, including Tokyo's Noel F. Busch, a former journalist with Time and Life magazines, ${ }^{76}$ and Hong Kong's James T. Ivy, a former foreign aid officer with the Economic Cooperation Administration. ${ }^{77}$

Why was the CIA, through the offices of the Asia Foundation, using American tax dollars to support the production of popular Korean films? The answer is that 
in the 1950s, commercial cinema in Asia was becoming a highly contested terrain in the cultural Cold War. Over the course of the decade, actors across the political spectrum in Asia treated entertainment films as a space in which their competing visions of modernity could be displayed before mass audiences, their ideologies simultaneously conveyed and masked by engaging stories and attractive styles.

Leftist films began finding wide audiences across Free Asia in the 1950s, which immediately caught the attention of the Asia Foundation and other cultural Cold Warriors in Washington. The People's Republic of China began exporting revolutionary films soon after coming to power in 1949. In 1954-55, its leaders shifted gears, launching a cultural diplomacy initiative that emphasized the production of films that would attract viewers with compelling content rather than hammering them with ideology. ${ }^{78}$ The result was a steady flow of well-made pictures, many of them opera films based on folktales and rich with evocations of regional and classical culture. These films, which launched a "golden age" of Chinese opera films, projected a benevolent image of China as it was claiming leadership of the nonaligned movement, and their nostalgic evocations of the motherland proved extremely popular among the millions of overseas Chinese in Southeast Asia-a population that was being wooed by both Beijing and Washington. In Hong Kong, Beijing provided subsidies to three leftist production companiesGreat Wall, Phoenix, and New Union-whose socially conscious films played to full houses in communist-owned theaters and were exported to Southeast Asian markets. ${ }^{79}$ In Japan, independent producers freed from occupation censorship rules were finding success with films that the Asia Foundation regarded as communist in ideology and anti-American in subject matter-films like Sekigawa Hideo's Mixed Blood Children (1952), which focused on orphans abandoned by their GI fathers, and Hiroshima (1953), which recreated the horrors of the atomic bombing. Imai Tadashi's The Tower of Lilies (1953) told a story, in John Miller's words, about "the American slaughter of Okinawan school girls" during the war; it became the biggest moneymaker in Japanese history. ${ }^{80}$ Similar to China's opera films, these often well-made leftist pictures marked the onset of the "golden age" of postwar Japanese cinema. ${ }^{81}$

The Asia Foundation, which had taken an interest in movies from its inception, sought ways to counter the market success of leftist films. In his 1956 report on the Korean film industry, John Miller voiced the foundation's belief in film's unparalleled ability to shape popular consciousness in Asia. Movies were a "powerful social, cultural, and political force" and the "most effective instrument for selling ideas," with a profound ability to "shape the lives" and attitudes of viewers, especially in areas where literacy rates were low and other forms of entertainment limited. TAF was adamant about not ceding this cultural ground to communists. In keeping with its initial orientation towards propaganda, it began by financing the production of individual documentaries (and at least one feature film, The People Win Through [1954], about the suppression of a communist insurrection 
in Burma) that were produced by Americans and aimed at Asians. ${ }^{82}$ These films, however, had a hard time reaching audiences. They were seen by too few viewers, failed to engage them emotionally, and were often regarded with indifference and suspicion. "The Asians," wrote Hong Kong representative James Ivy in 1952, "have been bombarded with propaganda from all sides and they can smell it a mile away." Commercial films, in contrast, were becoming the most important form of entertainment across postwar Asia, with low ticket prices and broad distribution networks that enabled them to reach more people than any other form of mass media. Foundation executives realized that "the peoples of Asia paid heed solely to films which reached them through their regular theaters and which were designed chiefly for entertainment." A new approach was clearly necessary. "To be effective," said Ivy, "we must find ways and means of getting the people themselves to do the job-with assistance from us behind the scenes." TAF president Robert Blum agreed, and in 1953 he redirected TAF's film program away from propaganda and towards entertainment-precisely the shift that China would soon make as well..$^{83}$ The objective was simple yet audacious: to help anticommunist filmmakers attract larger audiences by making better and more entertaining movies.

TAF launched several commercial film projects in response to leftist initiatives, with uneven success. Its first and most ambitious project was in Hong Kong. Between 1953 and 1959 the foundation poured more than \$500,000 into Asia Pictures, Ltd., a TAF-owned studio headed up by Cold War cultural entrepreneur Chang Kuo-sin, who aimed to make high-quality Mandarin films conveying a subtle "ideological message." After seven years, San Francisco concluded that the studio's political impact had been "minor, if not negligible": its films simply did not sell enough tickets in the target markets of Southeast Asia. ${ }^{84}$ TAF's Tokyo office, in turn, was receptive to a proposal from Cold War cultural entrepreneur Masaichi Nagata, the anticommunist head of Daiei studio. Eager to improve his films' quality and exportability, Nagata sought TAF's assistance in arranging coproductions with Hollywood studios. In 1954 TAF arranged for Hollywood screenwriter Winston Miller to spend five weeks consulting at Daiei and working on a screenplay that would attract a Hollywood partner. TAF regarded this project as a modest success. While it did not culminate in any coproductions, Tokyo representative Noel Busch claimed (perhaps optimistically) that Miller had achieved the "thorough indoctrination of the active, working writers and directors of Japan's most energetic film company in U.S. methods of production, story construction, editing, cutting, etc., with consequent absorption by these influential persons of the outlook of the western point of view generally." ${ }^{85}$

The foundation had better success with the Asian Film Festival (AFF), which became its main vehicle for supporting commercial cinema across the region. The festival was the brainchild of Daiei's Nagata, who sought to increase regional film exports in the wake of the global success of Rashomon (1950) and to forge ties among Asia's noncommunist film industries. He created the Federation of Motion 
Picture Producers Association of Asia (FPA), a regional professional organization that sponsored the festival. Launched in 1954, the AFF was the first major international film festival held in Asia and, like the Berlin Film Festival, it was a Cold War institution, open only to noncommunist countries. It was also an exemplary instance of TAF's modus operandi of supporting indigenous initiatives that aligned with Washington's interests. The festival harmonized with TAF's goals of strengthening noncommunist media production and binding Free Asia nations together through institutional, commercial, and personal ties. In addition to raising professional standards across the region by fostering cooperation and competition, TAF valued the festival as a site of cultural exchange: as filmmakers from across Asia watched each other's films, they would hopefully develop the international understanding that Washington saw as vital for the sustenance of Free Asia. The Asia Foundation supported the festival overtly and covertly throughout the 1950s, contributing financial and material resources, providing professional expertise and celebrities from Hollywood, and helping to police its ideological boundaries. ${ }^{86}$

The festival spurred TAF's interest in smaller film industries across the region, including South Korea's. While the festival was dominated in its early years by the more developed industries in Japan and Hong Kong, John Miller was convinced that the prestige of the event would "stimulate the comparatively backward film producers of Asia to higher quality production" as they focused their energies on making films good enough to enter and win prizes. The idea of aiding the Korean film industry seems to have originated in the Tokyo office in 1953, emerging out of early conversations with Nagata. Charles Tanner in San Francisco developed several preliminary proposals in 1953-54, drawing on the advice of his friend Oh Young-jin, who was touring the United States on a State Department grant. Seoul representative Philip Rowe set the project in motion in December 1954 after consulting with Korean officials on their most pressing cultural needs. One month later, in January 1955, John Miller arrived to perform his initial survey of the industry. ${ }^{87}$

Miller made clear in his February 1955 report that the fundamental issue in Korea was not competition from communist films, as was the case in Japan, Hong Kong, and Southeast Asia, but rather the lack of a material foundation on which an industry could be built. This lack of resources left filmmakers vulnerable to defection to the North, where a well-endowed state-run industry was taking shape. Rhee's government, paradoxically, also posed a danger. Miller warned that its monopoly on what little equipment did exist could easily turn into control over film content, stifling creativity and reducing cinema to mere propaganda, with its inevitable loss of popularity and thus ideological effectiveness. The Korean people, suffering as they were from social and economic dislocation, were in danger of becoming disillusioned with their fragile democracy. What they needed, according to Miller, was "information and entertainment which explains democratic ideals." 88 
Miller proposed, as had Oh Young-jin in his 1953 conversation with Charles Tanner, that TAF create an equipment rental company and film processing laboratory that would be available to all commercial producers. His proposal followed TAF's revised media guidelines, developed in the wake of the disappointing Asia Pictures and Daiei studio projects: it did not involve TAF in film production; it provided support for the industry as a whole, rather than a single studio; and it was structured as a single large infusion of aid rather than an ongoing subsidy. Budgeted at $\$ 58,000$, this was not intended as an elaborate studio. Miller characterized the equipment and facilities as "emergency measures designed to supply such needs only until private enterprise can, without subsidy, do the same job." The objective was to "stimulate" rather than underwrite a commercial industry: "Let us only give them a working chance." ${ }^{\text {99 }}$ Miller had faith that Korea's filmmakers would seize the opportunity.

San Francisco approved the proposal and Miller implemented it between June and December of 1956. When in October of that year Syngman Rhee asked TAF president Robert Blum for assistance for the film industry, he was pleased to hear that a project was already underway. Miller began by shepherding into existence a professional organization, the Korean Motion Picture Cultural Association (KMPCA), whose board of directors was composed of Cold War cultural entrepreneurs from across the film and media industries, including Oh Young-jin. ${ }^{90}$ This was one of the instances in which TAF had to create a local organization in order to fund it. Miller purchased modern equipment in Hollywood, including a $35 \mathrm{~mm}$ Mitchell synchronized sound camera and Korea's first automatic film-developing machine, and he curated a small library of Japanese and American technical books and two hundred recordings of music and sound effects. The KMPCA studio, as it was initially known, began operations in October 1956, a few months before the privately financed Samsung and Anyang studios. It immediately came into heavy use and within a few months was financially self-supporting. In August 1957 it moved to a new location northwest of Seoul, with a new soundstage built by a Korean investor, and became known as the Jeongneung studio. The automatic developing machine, which was operated by a USIS-trained technician and dramatically improved picture quality, proved particularly attractive to filmmakers and by 1958 was in operation twenty-four hours a day. Cho Tong-jae, program advisor in TAF's Seoul office, estimated that in the first half of 1958 over 80 percent of commercial producers used the lab to process their film..$^{91}$ In 1959, the KMPCA claimed that its equipment was being "used in producing nearly all the feature films produced in Korea." ${ }^{22}$

In addition to supplying it with material resources, the Seoul office nudged Korea's blossoming industry in a cosmopolitan direction by underwriting its participation in the Asian Film Festival throughout the 1950s. Rhee's Ministry of Education also supported participation in the festival by working with producers to select the entries. TAF advanced these efforts in diverse ways. The Seoul 
representatives encouraged the KMPCA to apply for membership in the Federation of Motion Picture Producers Association of Asia (FPA), smoothed the way for the application's quick approval, and made dollars available to pay the association's membership dues. They enabled Korea to send large delegations to the festival by paying the expenses for select members, and provided staffer Cho Tong-jae to act as translator and guide. They paid to send three observers to the 1955 festival in Singapore and for KMPCA board member Oh Young-jin to attend the 1958 festival in Manila as a judge. They even worked with TAF representatives in host cities across Asia to ensure that Korean delegations were accorded a positive reception. ${ }^{93}$ As Miller predicted, Korean filmmakers were eager to improve the quality of their films in order to have them accepted into the festival and win prizes. As a result of these combined efforts, at least eight Korean films screened in competition at the Asian Film Festival between 1957 and 1960. ${ }^{94}$ Several of these films won prizes, beginning in 1957 with The Wedding Day (1956), which was directed by KMPCA board member Lee Byung-il and written by fellow board member Oh Young-jin. Through TAF's efforts, the festival became an important venue for forging professional ties between Korean filmmakers and their counterparts overseas. Participation in the Asian Film Festival stimulated the exhibition of Korean films at other festivals across the Free World, including Berlin, Venice, and San Francisco. This festival exposure, in turn, stimulated the commercial export of Korean films (fourteen in 1958), including to the ideologically contested markets of Southeast Asia. ${ }^{95}$ All of this served to make South Korea visible to other Free World nationsa core TAF objective-as an independent country with its own unique cultural traditions, and as a modernizing one capable of producing technologically competent films within a capitalist mode of production.

Han's professional ambitions and the Asia Foundation's cosmopolitan agenda intersected at the Asian Film Festival. Han participated in every festival between 1956 and 1961, save one. He was a member of the delegations to Hong Kong in 1956, Tokyo in 1957, and Manila in 1961, and his films screened in competition in Manila in 1958 (Hyperbolae of Youth) and won an award in Kuala Lumpur in 1959 (Because I Love You [1958]). Han shared Miller's view on the importance of the festival as a spur to the improvement of Korean films and the modernization of its industry. After returning from Hong Kong in 1956, he wrote an article for the Chosón ilbo newspaper lamenting the underdeveloped state of Korea’s "newborn" film industry. He praised the festival as an "impetus" to improving the technical quality of Korean films so that they would become acceptable from an "international point of view" and thus able to compete at international festivals. ${ }^{96}$

By 1962 TAF considered the Korea project to be its most successful film program in Asia. The foundation's objectives had been achieved and a flourishing private commercial film industry had come into existence: there were now eight commercial film processing labs in Seoul, and individual production companies had become profitable enough to purchase their own equipment. More importantly, 
both the number and quality of films had improved significantly, and they were having "an increasing influence ... as an important cultural medium." The program had in fact exceeded foundation expectations. "The KMPCA has had a far broader influence than any of us hoped for in the beginning," wrote former Seoul representative Jack E. James, creating new jobs and outlets for creative energies and stimulating exhibitors to build new theaters. In light of this success, the foundation in 1962 closed out its stake in the studio and transferred the ownership of all the equipment to the KMPCA. Four years later, Cho Tong-jae summarized the effects of the project after meeting with the KMPCA membership: TAF's intervention in the industry had yielded "immediate and swift" results and had "virtually revolutionized motion picture production processes" by reducing costs and enhancing quality. "The Foundation support of the KMPCA has been, as is widely recognized in Korea," he reported, "directly contributory to the growth of the Korean motion picture industry into what it is today." ${ }^{97}$ No longer necessary in Korea's thriving commercial film industry and with its equipment worn out, the KMPCA dissolved itself in 1965 , its mission complete..$^{98}$

\section{HAN HYUNG-MO AS MODERNIZER}

Han Hyung-mo was, in many ways, exactly the type of filmmaker that TAF hoped to cultivate: a native modernizer of Korea's film industry and its cinema. He was, in the words of film scholar Chung Chong-hwa, the "pioneer of the well-made commercial film" and thus the father of the modern Korean cinema that blossomed in the 1950 s. Han's commercial success meant that he did not need to apply directly to TAF for assistance, in contrast to colleagues like Oh Young-jin and Lee Byung-il. He did, however, take advantage of TAF's interventions in postwar public culture and sometimes used the facilities at the KMPCA studio. ${ }^{99}$ More importantly, Han's ambitions for the development of the industry meshed closely with those of the Asia Foundation. Both TAF and Han shared a vision of a Korean film industry modernized along capitalist lines and producing popular films that expressed an optimistic attitude towards Western-style modernization.

Han's innovations were felt across all areas of filmmaking, including technology. Filmmakers and critics admired Han as a brilliant technician who understood, and was thus able to improve, the mechanical dimensions of filmmaking. Han introduced complex sound editing in Breaking the Wall. He built Korea's first camera crane for Madame Freedom and engineered a playback system capable of synchronizing music and image. He helped develop Korea's own anamorphic widescreen process- "Buksamscope"- which was first used in Poor Lovers (1959). And he was among the earliest directors to use synchronized sound effectively, in Because I Love You. ${ }^{100}$

Han saw the potential for Korea's "handicraft" operations to develop into an industrial mode of production, one that was rooted in secure companies that 
would make serial production possible. He possessed an astute commercial sensibility and aimed for the box office every time, understanding that each successful film provided the capital to produce the next one. In order to create an institutional foundation for his work, he founded Han Hyung-mo Productions in 1954 and two years later affiliated it with the Samsung Film Company. While the two companies shared personnel and resources, they divided responsibilities, with Han's company focused on production and Samsung on distribution. This type of business relationship was new and proved very successful. The two companies had a reputation, rare at the time, for completing their productions, for being honest with investors' money, and for using that money to make high-quality and profitable pictures. Generous with his production crews, Han was able to hire the most skilled people, who in turn gave him their best work. As a result, Han and Samsung had no problems raising investment capital from urban and provincial theater owners, who had confidence that they would get an audience-attracting picture in return. The phenomenal financial success of Madame Freedom secured the companies' standing and allowed them to enhance it by building their own production space, the Samsung Studio. Han's entrepreneurial sensibility enabled him to establish himself securely as an independent producer. He owned his own camera and editing equipment that he rented out to other filmmakers, had a stake in a production studio, and had valuable ties to the Ministry of Defense with its US-supplied equipment. ${ }^{101}$

Han Hyung-mo was also a modernizer of Korean cinema-of the films that this developing industry produced. Han used his technical skills to produce visual splendor. At a time when many of his colleagues struggled to convey a story clearly, Han understood how to use film form expressively. In doing so he earned the admiration of his peers. Director Lee Hyung-pyo recalled that Han's masterful cinematography on Hometown in the Heart (1949) - a lyrical film set in a mistshrouded Buddhist temple-made it the single most memorable film of the liberation era. Critics praised Breaking the Wall for its dramatic synthesis of ideological and personal conflict, holding it up as the standard to which other filmmakers should aim. Director Kim Kee-duk recalled the influence that Han's noirish spy melodrama The Hand of Destiny had on fellow filmmakers, with its expressive deployment of shadows, its surprising use of close-ups, and its sense of rhythm created by camera movement in combination with editing. Lighting directors, in turn, were in awe of Han's "fastidious" attention to lighting in all his films. ${ }^{102}$

Han also modernized the social function of film, abandoning the didactic role that had held sway since the colonial era in favor of mass entertainment in the tradition of Hollywood. With excitement rather than moral uplift as his goal, Han presented characters and scenes more scandalous than exemplary. ${ }^{103}$ He pursued originality. He engineered Korea's first on-screen kiss in The Hand of Destiny, sparked an uproar with his depiction of a professor's wife engaging in extramarital affairs in Madame Freedom, and presented Korea's first lesbian character in 
A Jealousy (1960). He introduced new genres into Korean cinema and combined them in innovative ways. Breaking the Wall created the anticommunist film as a distinct genre. Hyperbolae of Youth combined elements of the musical with those of the romantic comedy, a genre which Han developed further in A Female Boss (1959) and My Sister Is a Hussy (1961). Madame Freedom launched the modern melodrama. The Devil (1957) initiated the detective film. Many of his films incorporated elements of film noir.

What stood out most to Han's contemporaries was his ability to tap into Korea's emerging modern life. Han's films were deeply embedded within the larger public culture of which they were a vital part, and like budae jjigae they combined disparate elements into something new and delicious. Popular novels became scripts, fashionable restaurants appeared as sets, and hit songs permeated soundtracks. Han filled his productions with all that was fresh and dynamic, treating his films as portals into a cosmopolitan, metropolitan way of life. His characters go to nightclubs and listen to jazz, play miniature golf and watch bicycle races, read Reader's Digest and drink Coca Cola, dress in the latest Western fashions and flirt openly with each other. Han incorporated the latest trends into his films and repaid the loan by generating catchphrases and character types that lived well beyond the theater. The currents running through public culture ran through his films as well. His films made visible the ideas and forces that were eroding established traditions and ushering in something new: individualism, sexual liberation, capitalism. More profoundly, Han's films expressed an optimism about modernity. It was this attitude that set him apart from his peers, who, according to one contemporary critic, believed that a film "should show a monster called modernity chasing humans, what that monster is, and what is gained after fighting the monster." Han challenged that view, as well as the "culture of despair" manifested in neorealist films like Yu Hyun-mok's Aimless Bullet (1961) that appealed so powerfully to Korea's intellectuals. He was not naïve, however, and the corruptions of modern life-from tax evasion to the abuse of power-found frequent expression in his films. He presented modern urban life, in the words of Cho Junhyoung, "as both attractive and dangerous." ${ }^{104}$

Han's visual vocabulary of modern life overlapped significantly with that of Yŏwŏn, with images of glamour, consumption, and leisure figuring prominently in both. Most importantly, they shared a vision of women as active agents in public life. Han's films, like Yŏwŏn's pages, were full of working women from across the class spectrum, including shop girls, office workers, nurses, hairdressers, and media professionals. More strikingly, Han and Yŏwŏn depicted women as powerful, and they surrounded them with traditionally masculine markers of authority: stacks of money, towering modern buildings, guns. In Han's films as in Yŏwŏn's pages, one could see women working behind large desks and maneuvering through the city in big American cars. Several of Han's films even nodded towards Yŏwŏn in their storylines. A Female Boss revolves around a female publisher of a women's 


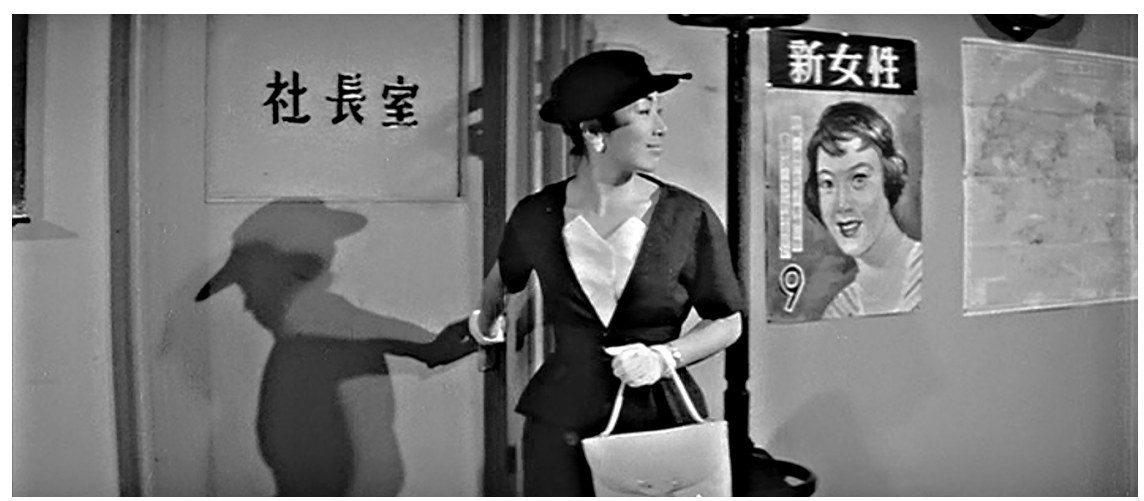

FIGURE 9. Fashionable magazine publisher (Jo Mi-ryeong) in A Female Boss (1958) with a cover of The Modern Woman and a world map. (Courtesy KOFA)

magazine, the cover of which cover strongly resembles Yŏwŏn's (figure 9), and Men $v s$. Women (1959) features an obstetrician heroine who is profiled in an admiring magazine spread acclaiming her as a successful professional woman. Actresses from Han's films, in turn, appeared regularly in Yŏwŏn's pages demonstrating the latest fashion trends.

Perhaps most powerfully, Han's films voiced the aspirations of the young postwar generation, portraying the possibilities-for work, love, and pleasure-that modernity was opening up. His films were not accurate depictions of typical Korean lives, which were often unspeakably difficult during these years. They are perhaps best understood, instead, as works of quasi-science fiction, proffering visions of a lifestyle that would not become widespread for another forty years. 